\title{
Androgenic suppression combined with radiotherapy for the treatment of prostate adenocarcinoma: a systematic review
}

\author{
André D Sasse $^{1 *}$, Elisa Sasse ${ }^{2}$, Albertina M Carvalho $^{3}$ and Ligia T Macedo ${ }^{1}$
}

\begin{abstract}
Background: Locally advanced prostate cancer is often associated with elevated recurrence rates. Despite the modest response observed, external-beam radiotherapy has been the preferred treatment for this condition. More recent evidence from randomised trials has demonstrated clinical benefit with the combined use of androgen suppression in such cases. The aim of this meta-analysis is to compare the combination of distinct hormone therapy modalities versus radiotherapy alone for overall survival, disease-free survival and toxicity.

Methods: Databases (MEDLINE, EMBASE, LILACS, Cochrane databases and ClinicalTrials.gov) were scanned for randomised clinical trials involving radiotherapy with or without androgen suppression in local prostate cancer. The search strategy included articles published until October 2011. The studies were examined and the data of interest were plotted for meta-analysis. Survival outcomes were reported as a hazard ratio with corresponding 95\% confidence intervals.

Results: Data from ten trials published from 1988 to 2011 were included, comprising 6555 patients. There was a statistically significant advantage to the use of androgen suppression, in terms of both overall survival and disease free survival, when compared to radiotherapy alone. The use of long-term goserelin (up to three years) was the strategy providing the higher magnitude of clinical benefit. In contrast to goserelin, there were no trials evaluating the use of other luteinizing hormone-releasing hormone (LHRH) analogues as monotherapy. Complete hormonal blockade was not shown to be superior to goserelin monotherapy.
\end{abstract}

Conclusions: Based on the findings of this systematic review, the evidence supports the use of androgen suppression with goserelin monotherapy as the standard treatment for patients with prostate cancer treated with radiotherapy, which are at high risk of recurrence or metastases.

\section{Background}

Prostate cancer is the second most prevalent neoplasm and the sixth leading cause of cancer mortality, with an estimated incidence of 903,500 new cases and 258,400 deaths in 2008 [1]. Historically, the incidence of this condition had a rapid increase during the early 1990s with later stabilization. This can be largely explained by the introduction of prostate specific antigen (PSA) testing, causing a sudden diagnosis boost worldwide. For the same reason, the distribution of prostate cancer

\footnotetext{
* Correspondence: sasse@cevon.com.br

${ }^{1}$ Center for Evidences in Oncology, Clinical Oncology Service, Internal Medicine Department Faculty of Medical Sciences, University of CampinasUNICAMP, 6111, 13083-970 Campinas, SP, Brazil

Full list of author information is available at the end of the article
}

cases was heterogeneous, with higher rates observed in the United States, Australia, Norway, Japan, Italy and others [2]. On the other hand, mortality has been declining in such countries, probably as a consequence of recent advances in treatment and support [3].

The advent of improved curative intent therapy for local disease has been suggested as one of the reasons for the decrease of prostate cancer deaths in the past decade. Current strategies for the management of localized prostate cancer consist of either surgical treatment or radiotherapy. Until the present, there has been no accurate comparison coming from randomized clinical trials evaluating the clinical efficacy of these strategies. Another reason could be related to response to therapy, which is highly dependent on other prognostic factors.
C Biomed Central

() 2011 Sasse et al; licensee BioMed Central Ltd. This article is published under license to BioMed Central Ltd. This is an Open Access article distributed under the terms of the Creative Commons Attribution License (http://creativecommons.org/licenses/by/2.0), which permits unrestricted use, distribution, and reproduction in any medium, provided the original work is properly cited. 
For example, patients classified as low-risk (PSA $\leq 10$ $\mathrm{ng} / \mathrm{ml}$, Gleason $\leq 6$, stage T1c or T2a) and treated with radiotherapy have better prognosis, with a reported 10 year mortality of $2 \%$, while higher risk patients face mortality rates ranging from $12 \%$ to $30 \%$ [4]. On the other hand, a surgical approach for locally advanced prostate cancer had shown cure rates of less than $25 \%$ [5]. Therefore, external-beam radiotherapy is usually the preferred treatment in this setting, due to an acceptable survival rate [6] and less morbidity than surgery. Nonetheless, patients with locally advanced disease have the worst prognosis and higher chances of relapse [7].

Since the 1970s, the role of androgen deprivation therapy adjuvant to radiotherapy to treat locally advanced prostate cancer has been investigated [8]. The inhibitory effect of androgen deprivation on the growth and proliferation of prostate cancer cells is well established. Several studies have shown a rapid regression of prostate cancer after total androgen blockade, leading to hypothesize that the marked regression observed at the prostatic level of both malignant and non-malignant tissue may increase radiation efficacy. In decreasing the tumor size by antiandrogen medication, an optimal dose of radiation could treat adequately prostate cancer with less adverse events.

In this context, androgen deprivation therapy has been a matter of discussion and study as a complementary treatment for high-risk patients. Evidence in favour of its use combined with radiotherapy has been described, with benefit in terms of overall survival [9]. However, the optimal time for introduction, duration of hormone therapy, and the type of suppression involved are still unanswered issues.

In this meta-analysis, the authors intended to summarize all the published data to perform appropriate comparisons between the different regimens used for androgen deprivation in patients receiving radiotherapy for localized or locally advanced prostate cancer.

\section{Methods}

\section{Search strategy}

Search strategies were performed in relevant electronic databases, including PubMed/MEDLINE, EMBASE, LILACS, ClinicalTrials.gov and The Cochrane Library for randomized studies evaluating radiotherapy with or without androgen suppression in patients with localized or locally advanced prostate cancer. Articles published or presented from January 1966 to October 2011 were identified. Details of the search strategy used for PubMed/MEDLINE are described separately (Table 1).

\section{Selection criteria}

The purpose of this study was to identify all published randomised, controlled clinical trials in English, Spanish or Portuguese, comparing radiotherapy with or without any androgen suppression (orchiectomy, luteinizing hormone-releasing hormone [LHRH] analogues, peripheral anti-androgens or estrogenic therapy) in localized (cT12) or locally advanced (T3-4 N0-2 M0) prostate carcinoma. We included studies that evaluated introduction of androgen suppression either before, during or after radiotherapy; and excluded those for which anti-androgenic treatment was performed in both arms. Two researchers (ES, AMC) independently examined the list of references, as well as article selection.

\section{Data extraction}

For identification purposes, the selected trials were named after their first author and year of publication. Overall survival (OS), disease-free survival (DFS) and toxicity were the main outcomes of interest. For continuous variables of survival, we looked for the original hazard ratios (HR). Whenever data reported were unavailable or incomplete for analysis, we attempted to estimate it by applying either the described number of events and the corresponding p-value for the log-rank statistic, or by transcription of survival curves as suggested by Parmar and colleagues [10]. In this case, calculations were then made through a spreadsheet developed by Tierney and colleagues [11].

\section{Statistical analysis and synthesis}

Evaluation of possible bias, as described by Sterne and colleagues [12] was performed by two authors (ADS, ES). Special focus was given to the availability of information about randomization, blinding, allocation concealment, description of dropouts, utilization of an intention-to-treat (ITT) analysis, and source of funding.

Meta-analyses for this study were conducted with RevMan 5.0 software (Cochrane Collaboration's Information Management System). Analyses of data consisted of the HR for time-to-event outcomes and odds ratio (OR) for dichotomous variables (adverse events) for which 95\% confidence intervals $(\mathrm{CI})$ were calculated and presented in forest plots. The diamond at the bottom of the plot summarizes the best estimate results (the width representing its corresponding 95\% CI). Statistical heterogeneity was evaluated with the chi-square test [13], and expressed using the $I^{2}$ index, as described by Higgins and colleagues [14]. If heterogeneity was detected $\left(I^{2}>\right.$ $50 \%)$, a possible explanation was investigated. The presence of possible publication bias regarding the first endpoint (OS) was investigated by a funnel plot.

\section{Results}

\section{Search results}

From 479 potential studies identified with the search strategies applied, ten published articles from 1988 to 
Table 1 Description of search terms used (for MEDLINE database)

\begin{tabular}{|c|c|}
\hline \#1 "goserelin acetate" & \#55 Prostacur \\
\hline \#2 goserelin & \#56 Prostica \\
\hline \#3 "ICl-118630" & \#57 SCH-13521 \\
\hline \#4 "ICl 118630" & \#58 "SCH 13521" \\
\hline \#5 “ICl118630” & \#59 "SCH13521" \\
\hline \#6 Zoladex & \#60 Prostogenat \\
\hline \#7 \#1 OR \#2 OR \#3 OR \#4 OR \#5 OR \#6 & \#61 Testotard \\
\hline \#8 Leuprorelin & \#62 Apimid \\
\hline \#9 Enantone & \#63 \#34 OR \#35 OR \#36 OR \#37 OR \#38 OR \#39 OR \#40 \\
\hline \#10 "Leuprolide Acetate" & OR \#41 OR \#42 OR \#43 \\
\hline \#11 "Leuprolide Monoacetate" & OR \#44 OR \#45 OR \#46 OR \#47 OR \#48 OR \#49 OR \\
\hline \#12 Lupron & $\# 50$ OR \#51 OR \#52 \\
\hline \#13 “TAP-144" & OR \#53 OR \#54 OR \#55 OR \#56 OR \#57OR \#58 OR \\
\hline \#14 "TAP 144" & $\# 59$ OR \#60 OR \#61 \\
\hline \#15 “TAP144” & OR \#62 \\
\hline \#16 “A-43818” & \#64 Receptal \\
\hline \#17 "A 43818” & \#65 Buserelin \\
\hline \#18 "A43818" & \#66 Bigonist \\
\hline \#19 \#8 OR \#9 OR \#10 OR \#11 OR \#12 OR \#13 OR \#14 & \#67 Tiloryth \\
\hline OR \#15 OR \#16 OR \#17 & \#68 Profact \\
\hline $\mathrm{OR} \# 18$ & \#69 Suprecur \\
\hline \#20 diethylstilbestrol & \#70 Suprefact \\
\hline \#21 "Stilbene Estrogen" & \#71 "HOE-766" \\
\hline \#22 Stilbestrol & \#72 "HOE 766" \\
\hline \#23 Apstil & \#73 "HOE766" \\
\hline \#24 Tampovagan & \#74 \#64 OR \#65 OR \#66 OR \#67 OR \#68 OR \#69 OR \#70 \\
\hline \#25 Distilbène & OR \#71 OR \#72 OR \#73 \\
\hline \#26 Agostilben & \#75 cyproterone \\
\hline \#27 \#20 OR \#21 OR \#22 OR \#23 OR \#24 OR \#25 OR \#26 & \#76 Androcur \\
\hline \#28 "ICl-176334" & \#77 Cyprone \\
\hline \#29 “ICl 176334” & \#78 Cyprostat \\
\hline \#30 Casodex & \#79 "SH 714" \\
\hline \#31 bicalutamide & \#80 "SH-714" \\
\hline \#32 Cosudex & \#81 "SH714" \\
\hline \#33 \#28 OR \#29 OR \#30 OR \#31 OR \#32 & \#82 \#75 OR \#76 OR \#77 OR \#78 OR \#79 OR \#80 OR \#81 \\
\hline \#34 Niftolid* & \#83 Orchiectom* \\
\hline \#35 flutamide & \#84 Castration* \\
\hline \#36 Chimax & \#85 \#83 OR \#84 \\
\hline \#37 Cytamid & \#86 prostate \\
\hline \#38 Eulexin* & \#87 prostatic \\
\hline \#39 Drogenil & \#88 \#86 OR \#87 \\
\hline \#40 Euflex & \#89 neoplasm* \\
\hline \#41 Fluken & \#90 Cancer* \\
\hline \#42 Flulem & \#91 Tumor* \\
\hline \#43 Flumid & \#92 Malignan* \\
\hline \#44 Fluta 1A Pharma & \#93 \#89 OR \#90 OR \#91 OR \#92 \\
\hline \#45 "Fluta-cell" & \#94 radiotherap* \\
\hline \#46 "Fluta cell" & \#95 "external beam radiation" \\
\hline \#47 Flutacell & \#96 radiation \\
\hline \#48 Flutamin & \#97 brachitherapy \\
\hline \#49 Flutandrona & \#98 \#94 OR \#95 OR \#96 OR \#97 \\
\hline \#50 Flutaplex & \#99 random* \\
\hline
\end{tabular}


Table 1 Description of search terms used (for MEDLINE database) (Continued)

$\begin{array}{lc}\text { \#51 Flutexin } & \text { \#100 \#7 AND \#19 AND \#27 AND \#33 AND \#63 AND \#74 } \\ \text { \#52 Fugerel } & \text { AND \#82 AND \#85 AND } \\ \text { \#53 Grisetin } & \text { \#88 AND \#93 AND \#98 AND \#99 }\end{array}$

2011 were included, comprising 6555 enrolled patients. The literature search results are summarized in Figure 1.

Concerning the methods of androgenic deprivation therapy evaluated in these studies, three trials involved central blockade (through goserelin $[15,16]$ or orchiectomy [17]), while four studied combined suppression with flutamide [18-22], one used peripheral blockade with bicalutamide [23], and another study reported the use of estrogenic treatment [8]. Further details on study design and treatment modalities are described in Tables 2 and 3, respectively.

\section{Overall survival}

Data regarding OS was available in nine trials. Only four presented statistically significant results in favour of androgen deprivation. The funnel plot analysis performed confirmed the absence of publication bias. Due to the high overall heterogeneity observed between trials, we conducted subgroup analyses for more homogeneous comparisons.

\section{Overall survival per androgen suppression modality}

The use of goserelin combined with radiotherapy was associated with a $28 \%$ reduction of the risk of death (OS results: HR 0.72 , 95\% CI $0.60-0.87, P=0.0008$ ) (Figure $2)$. Although some heterogeneity was noted $\left(I^{2}=50 \%\right)$, the advantage of hormone therapy was present in all

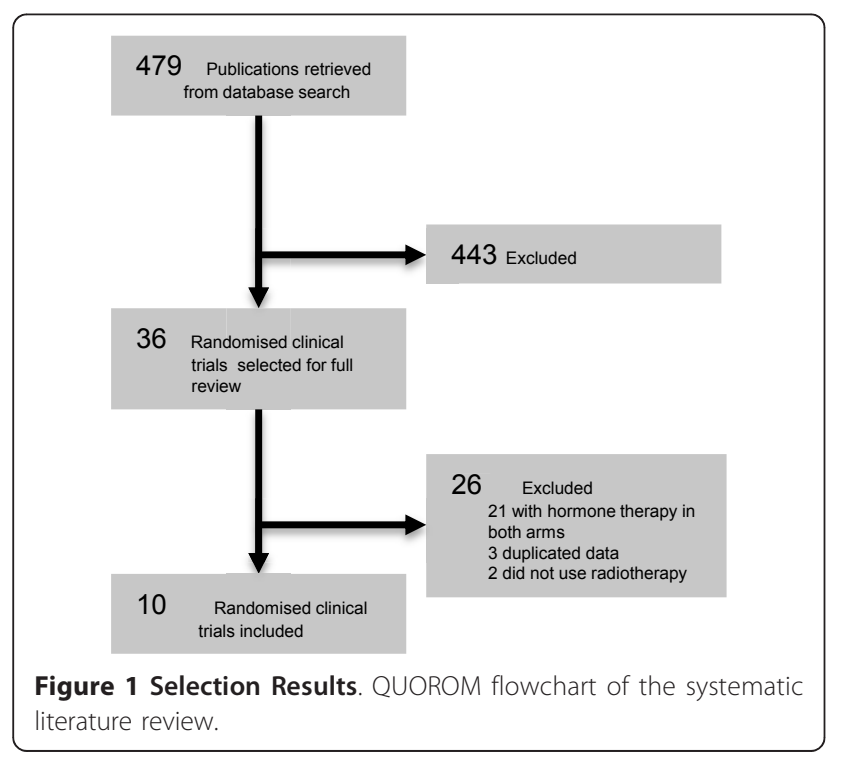

studies. A probable cause for this could be the diverse treatment durations leading to distinct clinical efficacy data.

In two trials [20,21], either goserelin or leuprolide was combined with flutamide. The high heterogeneity $\left(I^{2}=\right.$ $62 \%)$ precludes the interpretation of the meta-analysis, and can be explained by the different inclusion criteria from the trials.

In case of orchiectomy, one study showed the same pattern of advantage, yet failed to demonstrate statistical significance of the benefit (HR 0.62, 95\% CI 0.36-1.05, P $=0.08)$. This finding may be explained by the small number of patients included in the analysis.

The use of bicalutamide or estrogenic therapy without LHRH analogues did not result in evidence of OS benefit (HR 0.85, 95\% CI 0.70-1.04, and HR 1.00, 95\% CI 0.48-2.07, respectively).

Overall survival according to hormonal blockade (central or complete)

The analysis of central blockade identified three studies: two with goserelin and one with orchiectomy. This subgroup analysis demonstrated that the addition of androgen suppression (defined as central blockade) led to a $39 \%$ reduction in the risk of death (HR 0.61, 95\% CI $0.47-0.81, P=0.0005)$. However, the use of complete hormonal blockade with peripheral suppressors did not result in a significant advantage (HR 0.79, 95\% CI 0.690.90, $P=0.0003$ ) (Figure 3).

\section{Overall survival according to the duration of therapy}

We divided this subgroup in two sections: studies related to treatment for up to 6 months, and studies reporting durations of 1 year or more. In both subgroups, the use of hormonal therapy was significantly better, while shorter courses of treatment demonstrated a $21 \%$ reduction in the risk of mortality (HR $0.79,95 \%$ CI $0.69-0.90, P=0.0003)$, longer treatment durations provided benefits of an even greater magnitude (HR 0.61, 95\% CI 0.47-0.81, $P=0.0005$ ) (Figure $4)$. The interaction test shows a statistical difference between these subgroups $\left(I^{2}=76 \% ; p=0.04 \%\right)$.

\section{Disease-free survival}

In the studies related to orchiectomy and estrogenic treatment, DFS information was unavailable. Regarding the available data, similar to the OS analysis, high heterogeneity was present for DFS evaluation. Therefore, 
Table 2 Methodological characteristics of clinical trials

\begin{tabular}{llllllllll}
\hline Author & Year & Rand. & Alloc. & Blind. & Desc. losses & Sample Size & ITT & Multic. & Sponsor \\
\hline Zagars & 1988 & NS & NS & No & Yes & No & No & No & Public \\
\hline Laverdiere & 2004 & NS & NS & No & No & No & Ns & No & NS \\
\hline Lawton & 2005 & Yes & Yes & No & Yes & Yes & No & Yes & NS \\
\hline Granfors & 2006 & NS & NS & No & Yes & Yes & Yes & No & Public \\
\hline See & 2006 & Yes & Yes & Yes & Yes & Yes & Yes & Yes & Industry \\
\hline D'Amico & 2008 & Yes & Yes & No & Yes & Yes & Yes & Yes & Public \\
\hline Roach & 2008 & NS & NS & No & Yes & Yes & Yes & Yes & Public \\
\hline Bolla & 2010 & Yes & Yes & No & Yes & Yes & Yes & Yes & Both \\
\hline Denham & 2011 & Yes & Yes & No & Yes & Yes & No & No & Both \\
\hline Jones & 2011 & Yes & Yes & No & Yes & Yes & Yes & Yes & Public \\
\hline
\end{tabular}

Abbreviations: Alloc allocation concealment, Blind blinding, Desc. Losses description of losses to follow-up, ITT intention-to-treat analysis, Multic multicentric, NS not stated, Rand adequate randomization method, Sample Size adequate planning and calculation of sample size

subgroup analyses were performed to better understand the results, though statistically significant advantages were observed in all individual trials.

\section{Disease-free survival per androgen suppression modality}

The use of goserelin demonstrated an absolute reduction in recurrence of $47 \%$ (HR $0.53,95 \%$ CI $0.43-0.65, P$ $<0.00001$ ) (Figure 5). Similar to findings previously detected in the OS analysis, high heterogeneity was observed for this outcome $\left(I^{2}=74 \%\right)$. The main font of heterogeneity was the shortest-term blockade arm (3 month) of Denham's study. Excluding this trial, the heterogeneity becomes acceptable $\left(I^{2}=50 \%\right)$ and the reduction on recurrence associated with goserelin was more pronounced (HR 0.49, 95\% CI 0.42-0.58, $P<$ $0.00001)$.
Two studies analyzed the association of both goserelin and leuprolide to flutamide, also demonstrating benefit in DFS as well (HR 0.48, 95\% CI 0.30-0.77, $P=0.002$ ). One study evaluated the association of leuprolide to flutamide, with a significant benefit to patients receiving hormonal therapy (HR 0.55, 95\% CI 0.34-0.90, $P=0.02$ ). Additionally, an advantage to hormone therapy was observed also in the single study with bicalutamide (HR 0.61, 95\% CI 0.52-0.72, $P=0.00001)$. Further details are described in Figure 5.

\section{Disease-free survival according to hormonal blockade} (central or complete)

Two trials reported data regarding central blockade with goserelin (Figure 6), from which the meta-analysis showed benefit from the use of hormone therapy, reducing the risk of relapse in 57\% (HR 0.43, 95\% CI 0.37-

Table 3 Designed therapies

\begin{tabular}{|c|c|c|c|c|c|c|}
\hline Author & Year & Radiotherapy (dose) & Hormone Therapy & Duration & $\mathbf{N}$ & Median follow up \\
\hline Zagars & 1988 & 70 Gy & Diethylstilbestrol 25 mg PO qd & Continuously & 82 & 14.5 years \\
\hline Laverdiere & 2004 & 64 Gy & $\begin{array}{l}\text { Leuprolide } 7.5 \mathrm{mg} / \mathrm{month}+ \\
\text { Flutamide }\end{array}$ & $\begin{array}{l}3 \text { months } \\
\text { or } \\
10 \text { months }\end{array}$ & 161 & 5 years \\
\hline Lawton & 2005 & 65 to 70 Gy & Goserelin 3.6 mg/month & Continuously & 977 & 6.5 years \\
\hline Granfors & 2006 & 60 to $70 \mathrm{~Gy}$ & Orchiectomy & Permanent & 91 & 9.7 years \\
\hline See & 2006 & NS & Bicalutamide 150 mg PO qd & Decided by investigator & 1370 & 7.2 years \\
\hline D'Amico & 2008 & NS & $\begin{array}{c}\text { Goserelin } 3,6 \mathrm{mg} \text { or } \\
\text { Leuprolide } 7.5 \mathrm{mg} / \mathrm{month}+ \\
\text { Flutamide }\end{array}$ & 6 months & 206 & 8.2 years \\
\hline Roach & 2008 & 65 to 70 Gy & Goserelin 3.6 mg/month + Flutamide & 3 months & 456 & 11.9 years \\
\hline Bolla & 2010 & 70 Gy & Goserelin 3.6 mg/month & 3 years & 415 & 9.1 years \\
\hline Denham & 2011 & 66 Gy & $\begin{array}{l}\text { Goserelin } 3.6 \mathrm{mg} / \mathrm{month}+ \\
\text { Flutamide }\end{array}$ & $\begin{array}{l}3 \text { months } \\
\text { or } \\
6 \text { months }\end{array}$ & 818 & 10.6 years \\
\hline Jones & 2011 & 66.6 Gy & $\begin{array}{c}\text { Goserelin } 3,6 \mathrm{mg} \text { or } \\
\text { Leuprolide } 7.5 \mathrm{mg} / \mathrm{month}+ \\
\text { Flutamide }\end{array}$ & 4 months & 1979 & 9.1 years \\
\hline
\end{tabular}




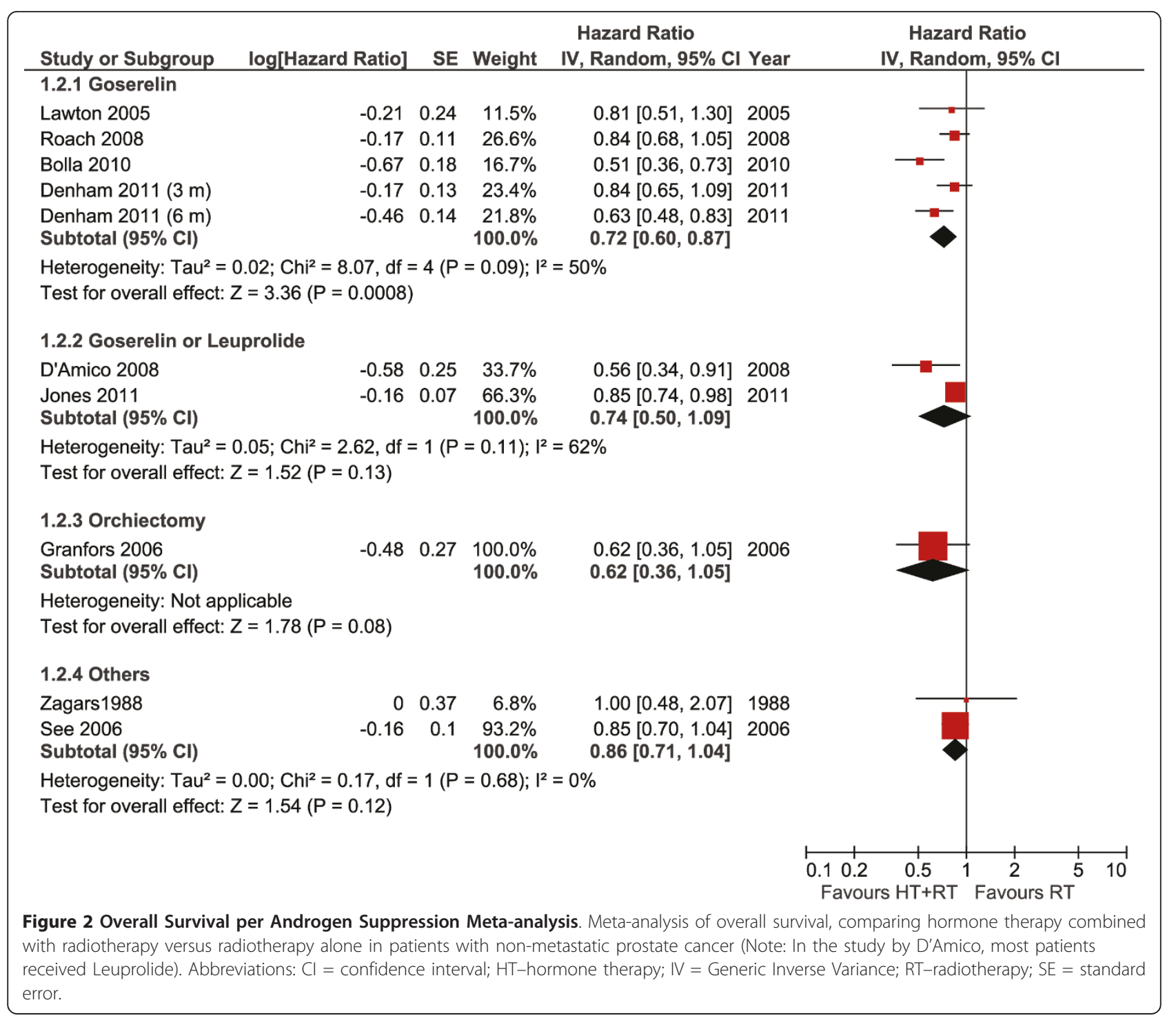

$0.49, P<0.00001)$. As with complete blockade with the combination of flutamide, the gain for DFS appeared to be similar to that observed for isolated goserelin (HR 0.57, 95\% CI 0.51-0.65, $P<0.00001$ ).

\section{Disease-free survival according to the duration of therapy}

The treatment with androgen suppression for a period not longer than 6 months (Figure 7) demonstrated the reduction of $43 \%$ in the risk of relapse (HR 0.57, 95\% CI $0.50-0.65, P<0.00001)$. Three other studies evaluated the duration of more than 1 year of therapy, with greater benefits, with a reduction of $57 \%$ in the risk of relapse (HR 0.43, 95\% CI 0.38-0.50, $P<0.00001$ ).

\section{Toxicity}

Unfortunately, data extraction was compromised for this outcome as a consequence of poor reporting of adverse events among trials. Nonetheless, when trials were analysed individually, there were apparently no reports of increased toxicity.

\section{Discussion}

An overall conclusion of this review and meta-analysis is that androgen deprivation therapy can be significantly beneficial for patients in terms of DFS and OS, when combined with radiotherapy. Nevertheless, many strategies for suppression have been studied so far, with conflicting results regarding efficacy and tolerability.

Estrogen therapy in high doses seems to be linked with higher risks of cardiovascular and thromboembolic events [24], but more importantly, failed to produce benefit in a small, single trial of 84 patients. The trials evaluating the performance of orchiectomy indicated a 


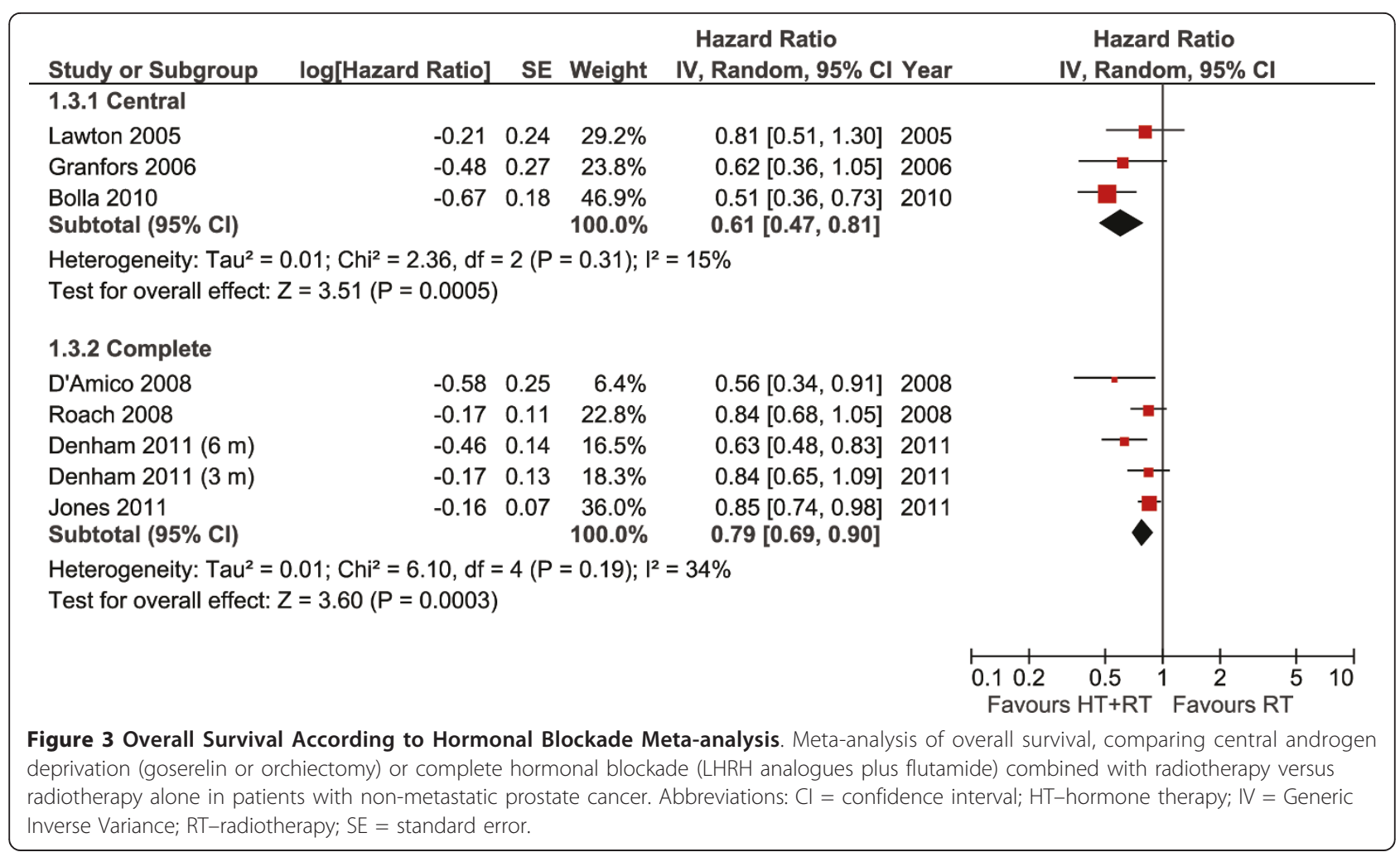

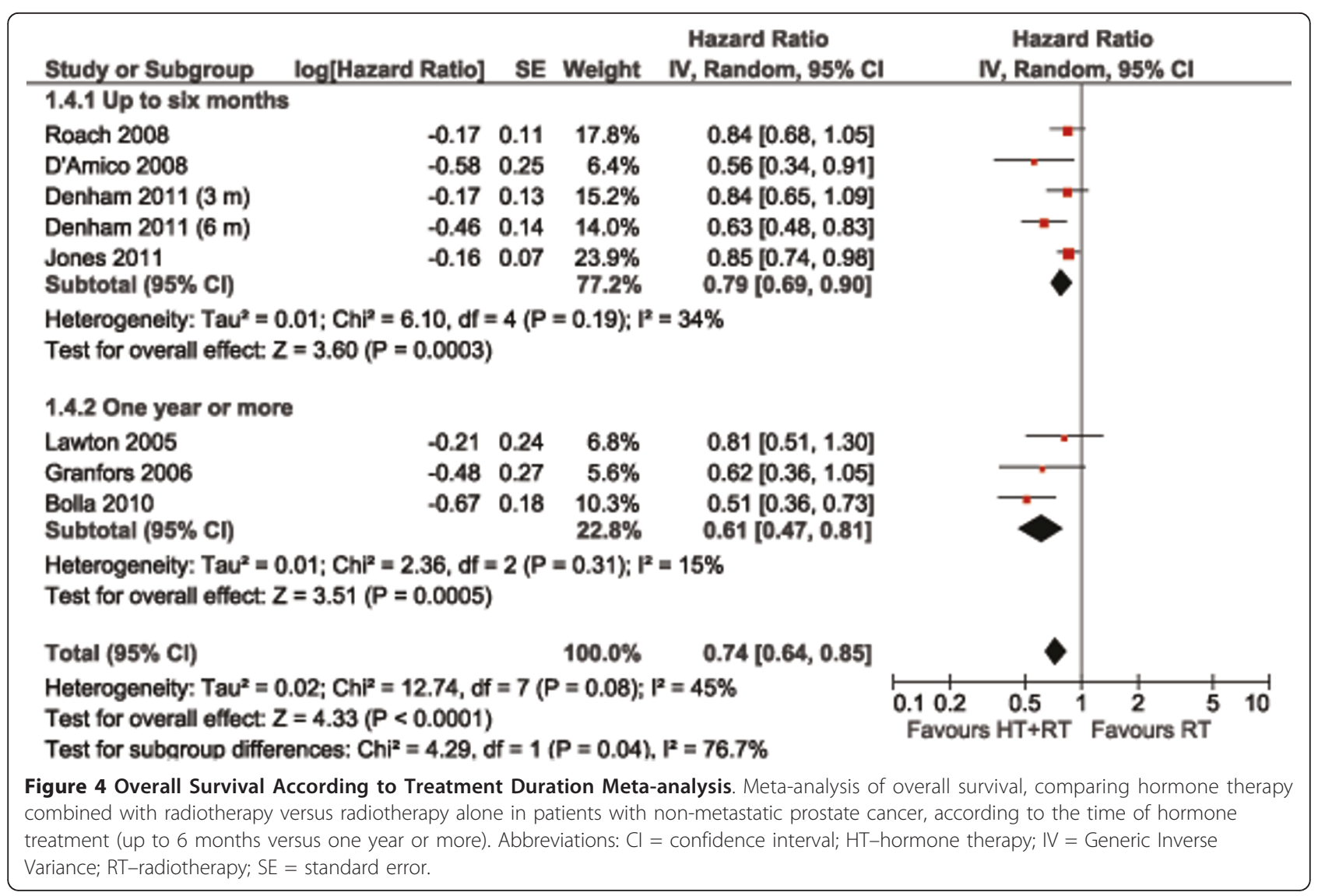




\begin{tabular}{|c|c|c|c|c|c|c|c|}
\hline \multirow{2}{*}{$\begin{array}{l}\text { Study or Subgroup } \\
2.1 .1 \text { Goserelin }\end{array}$} & log[Hazard Ratio] & \multirow[t]{2}{*}{ SE } & \multirow[t]{2}{*}{ Weight } & \multirow[t]{2}{*}{$\begin{array}{l}\text { Hazard Ratio } \\
\text { IV, Random, } 95 \% \mathrm{CI}\end{array}$} & \multirow[t]{2}{*}{ Year } & \multicolumn{2}{|c|}{$\begin{array}{c}\text { Hazard Ratio } \\
\text { IV, Random, 95\% CI }\end{array}$} \\
\hline & & & & & & & \\
\hline Lawton 2005 & -0.85 & 0.08 & $24.2 \%$ & $0.43[0.37,0.50]$ & 2005 & & \\
\hline Roach 2008 & -0.62 & 0.11 & $21.3 \%$ & $0.54[0.43,0.67]$ & 2008 & & \\
\hline Bolla 2010 & -0.87 & 0.21 & $12.8 \%$ & $0.42[0.28,0.63]$ & 2010 & & \\
\hline Denham 2011 (3 m) & -0.33 & 0.12 & $20.4 \%$ & $0.72[0.57,0.91]$ & 2011 & -- & \\
\hline $\begin{array}{l}\text { Denham } 2011(6 \mathrm{~m}) \\
\text { Subtotal }(95 \% \mathrm{Cl})\end{array}$ & -0.56 & 0.11 & $\begin{array}{r}21.3 \% \\
100.0 \%\end{array}$ & $\begin{array}{l}0.57[0.46,0.71] \\
0.53[0.43,0.65]\end{array}$ & 2011 & & \\
\hline \multicolumn{8}{|c|}{$\begin{array}{l}\text { Heterogeneity: } \mathrm{Tau}^{2}=0.04 ; \mathrm{Chi}^{2}=15.16, \mathrm{df}=4(\mathrm{P}=0.004) ; \mathrm{I}^{2}=74 \% \\
\text { Test for overall effect: } \mathrm{Z}=6.27(\mathrm{P}<0.00001)\end{array}$} \\
\hline \multicolumn{8}{|c|}{ 2.1.2 Goserelin or Leuprolide + flutamide } \\
\hline D'Amico 2008 & -1.05 & 0.27 & $36.7 \%$ & $0.35[0.21,0.59]$ & 2008 & & \\
\hline $\begin{array}{l}\text { Jones } 2011 \\
\text { Subtotal }(95 \% \mathrm{CI})\end{array}$ & -0.55 & 0.08 & $\begin{array}{r}63.3 \% \\
100.0 \%\end{array}$ & $\begin{array}{l}0.58[0.49,0.67] \\
0.48[0.30,0.77]\end{array}$ & 2011 & & \\
\hline \multicolumn{8}{|c|}{$\begin{array}{l}\text { Heterogeneity: } \mathrm{Tau}^{2}=0.09 ; \mathrm{Chi}^{2}=3.15, \mathrm{df}=1(P=0.08) ; \mathrm{I}^{2}=68 \% \\
\text { Test for overall effect: } Z=3.04(P=0.002)\end{array}$} \\
\hline \multicolumn{8}{|c|}{ 2.1.3 Leuprolide+flutamide } \\
\hline $\begin{array}{l}\text { Laverdiere } 2004 \\
\text { Subtotal }(95 \% \mathrm{CI})\end{array}$ & -0.6 & 0.25 & $\begin{array}{l}100.0 \% \\
100.0 \%\end{array}$ & $\begin{array}{l}0.55[0.34,0.90] \\
0.55[0.34,0.90]\end{array}$ & & & \\
\hline \multicolumn{8}{|c|}{$\begin{array}{l}\text { Heterogeneity: Not applicable } \\
\text { Test for overall effect: } Z=2.40(P=0.02)\end{array}$} \\
\hline \multicolumn{8}{|l|}{ 2.1.4 Bicalutamide } \\
\hline $\begin{array}{l}\text { See } 2006 \\
\text { Subtotal }(95 \% \mathrm{Cl})\end{array}$ & -0.49 & 0.08 & $\begin{array}{l}100.0 \% \\
100.0 \%\end{array}$ & $\begin{array}{l}0.61[0.52,0.72] \\
0.61[0.52,0.72]\end{array}$ & 2006 & & \\
\hline \multicolumn{8}{|c|}{$\begin{array}{l}\text { Heterogeneity: Not applicable } \\
\text { Test for overall effect: } Z=6.13(P<0.00001)\end{array}$} \\
\hline & & & & & & $\begin{array}{lc}0.2 & 0.5 \\
\text { Favours } \mathrm{HT}+\mathrm{RT}\end{array}$ & $\begin{array}{c}2 \\
\text { Favours RT }\end{array}$ \\
\hline \multicolumn{8}{|c|}{$\begin{array}{l}\text { Figure } 5 \text { Disease Free Survival per Androgen Suppression Meta-analysis. Meta-analysis of disease-free survival, comparing hormone therapy } \\
\text { combined with radiotherapy versus radiotherapy alone in patients with non-metastatic prostate cancer. Abbreviations: Cl = confidence interval; } \\
\text { HT-hormone therapy; IV = Generic Inverse Variance; RT-radiotherapy; SE = standard error. }\end{array}$} \\
\hline
\end{tabular}

possible advantage to its use, though lacking statistical significance. For the reasons stated, we concluded that there is no evidence so far, to support the use of definite deprivation for such patients, nor accurate analyses of possible long-term toxicity. Hence, current studies point toward androgen suppression with LHRH analogues as more advantageous in these cases. Until the present time, goserelin was the most studied compound in this category. Further studies are warranted to demonstrate a similar benefit from other types of analogues. Additionally, combination therapy with peripheral blockade did not offer a major benefit in comparison to goserelin monotherapy.

There is still much discussion about the comparison of LHRH analogues to surgical castration regarding testosterone levels. Chemical androgen deprivation is reported to be similar among the different types of analogues used, although there is fear that sudden elevations in the level of testosterone, according to distinct pharmacodynamic characteristics, could interfere with treatment and ultimately compromise survival [25]. Authors of a recent systematic review did not provide evidence of such a presumed effect from the analogues used in practice [26].

Our study also suggested that longer androgen suppression results in better DFS and OS. Those observations are in accordance to a previous systematic review focusing the duration of deprivation therapy [27], and a randomized clinical trial comparing 6 months versus 2 years of treatment [28].

Some limiting factors in this meta-analysis must be highlighted. There were different schedules of treatment resulting in the high heterogeneity described and the distinct patient selection criteria applied from each investigator. One example is the trial from Bolla and colleagues [16], presenting the greatest reported benefit in survival with the use of 3 years of goserelin after completion of radiotherapy. Though statistically 


\begin{tabular}{|c|c|c|c|c|c|c|}
\hline Study or Subgroup & log[Hazard Ratio] & SE & Weight & $\begin{array}{l}\text { Hazard Ratio } \\
\text { IV, Random, } 95 \% \mathrm{CI}\end{array}$ & $\begin{array}{r}\text { Hazar } \\
\text { IV, Rand }\end{array}$ & $\begin{array}{l}\text { Ird Ratio } \\
\text { dom, } 95 \% \mathrm{Cl}\end{array}$ \\
\hline \multicolumn{7}{|l|}{ 2.2.1 Central } \\
\hline Lawton 2005 & -0.85 & 0.08 & $87.3 \%$ & $0.43[0.37,0.50]$ & & \\
\hline $\begin{array}{l}\text { Bolla } 2010 \\
\text { Subtotal }(95 \% \mathrm{CI})\end{array}$ & -0.87 & 0.21 & $\begin{array}{r}12.7 \% \\
100.0 \%\end{array}$ & $\begin{array}{l}0.42[0.28,0.63] \\
0.43[0.37,0.49]\end{array}$ & & \\
\hline \multicolumn{7}{|c|}{$\begin{array}{l}\text { Heterogeneity: } \mathrm{Tau}^{2}=0.00 ; \mathrm{Chi}^{2}=0.01, \mathrm{df}=1(\mathrm{P}=0.93) ; \mathrm{I}^{2}=0 \% \\
\text { Test for overall effect: } Z=11.40(P<0.00001)\end{array}$} \\
\hline \multicolumn{7}{|l|}{ 2.2.2 Complete } \\
\hline Laverdiere 2004 & -0.6 & 0.25 & $5.7 \%$ & $0.55[0.34,0.90]$ & & \\
\hline D'Amico 2008 & -1.05 & 0.27 & $5.0 \%$ & $0.35[0.21,0.59]$ & & \\
\hline Roach 2008 & -0.62 & 0.11 & $20.7 \%$ & $0.54[0.43,0.67]$ & & \\
\hline Denham 2011 (3 m) & -0.33 & 0.12 & $18.5 \%$ & $0.72[0.57,0.91]$ & $\longrightarrow$ & \\
\hline Denham 2011 (6 m) & -0.56 & 0.11 & $20.7 \%$ & $0.57[0.46,0.71]$ & $\rightarrow-$ & \\
\hline $\begin{array}{l}\text { Jones } 2011 \\
\text { Subtotal }(95 \% \mathrm{Cl})\end{array}$ & -0.55 & 0.08 & $\begin{array}{r}29.5 \% \\
100.0 \%\end{array}$ & $\begin{array}{l}0.58[0.49,0.67] \\
0.57[0.51,0.65]\end{array}$ & & \\
\hline \multicolumn{7}{|c|}{$\begin{array}{l}\text { Heterogeneity: } \mathrm{Tau}^{2}=0.01 ; \mathrm{Chi}^{2}=7.24, \mathrm{df}=5( \\
\text { Test for overall effect: } \mathrm{Z}=8.79(\mathrm{P}<0.00001)\end{array}$} \\
\hline & & & & & $\begin{array}{ll}0.2 & 0.5 \\
\text { Favours } & \mathrm{HT}+\mathrm{RT}\end{array}$ & $12 \frac{1}{2} \quad 5$ \\
\hline \multicolumn{7}{|c|}{$\begin{array}{l}\text { Figure } 6 \text { Disease Free Survival According to Hormonal Blockade Meta-analysis. Meta-analysis of disease-free survival, comparing androgen } \\
\text { deprivation (goserelin or orchiectomy) or complete hormonal blockade (combination of flutamide) combined with radiotherapy versus } \\
\text { radiotherapy alone in patients with non-metastatic prostate cancer. Abbreviations: Cl = confidence interval; HT-hormone therapy; IV = Generic } \\
\text { Inverse Variance; RT-radiotherapy; SE = standard error. }\end{array}$} \\
\hline
\end{tabular}

\begin{tabular}{|c|c|c|c|c|c|c|}
\hline Study or Subgroup & log[Hazard Ratio] & SE & Weight & $\begin{array}{c}\text { Hazard Ratio } \\
\text { IV, Random, } 95 \% \mathrm{Cl}\end{array}$ & $\begin{array}{r}\text { Hazar } \\
\text { IV, Rand }\end{array}$ & $\begin{array}{l}\text { rd Ratio } \\
\text { lom, } 95 \% \mathrm{Cl}\end{array}$ \\
\hline \multicolumn{7}{|c|}{ 2.3.1 Up to six months } \\
\hline Laverdiere 2004 & -0.76 & 0.37 & $3.0 \%$ & $0.47[0.23,0.97]$ & & \\
\hline D'Amico 2008 & -1.05 & 0.27 & $5.4 \%$ & $0.35[0.21,0.59]$ & & \\
\hline Roach 2008 & -0.62 & 0.11 & $21.4 \%$ & $0.54[0.43,0.67]$ & - & \\
\hline Denham 2011 (3 m) & -0.33 & 0.12 & $19.2 \%$ & $0.72[0.57,0.91]$ & $\rightarrow$ & \\
\hline Denham 2011 (6 m) & -0.56 & 0.11 & $21.4 \%$ & $0.57[0.46,0.71]$ & - & \\
\hline $\begin{array}{l}\text { Jones } 2011 \\
\text { Subtotal }(95 \% \mathrm{CI})\end{array}$ & -0.55 & 0.08 & $\begin{array}{r}29.7 \% \\
100.0 \%\end{array}$ & $\begin{array}{l}0.58[0.49,0.67] \\
0.57[0.50,0.65]\end{array}$ & $\vec{r}$ & \\
\hline \multicolumn{7}{|c|}{$\begin{array}{l}\text { Heterogeneity: } \mathrm{Tau}^{2}=0.01 ; \mathrm{Chi}^{2}=7.53, \mathrm{df}=5(\mathrm{P}=0.18) ; \mathrm{I}^{2}=34 \% \\
\text { Test for overall effect: } \mathrm{Z}=8.47(\mathrm{P}<0.00001)\end{array}$} \\
\hline \multicolumn{7}{|c|}{ 2.3.2 One year or more } \\
\hline Laverdiere 2004 & -0.46 & 0.33 & $4.9 \%$ & $0.63[0.33,1.21]$ & & \\
\hline Lawton 2005 & -0.85 & 0.08 & $83.1 \%$ & $0.43[0.37,0.50]$ & & \\
\hline $\begin{array}{l}\text { Bolla } 2010 \\
\text { Subtotal }(95 \% \mathrm{Cl})\end{array}$ & -0.87 & 0.21 & $\begin{array}{r}12.1 \% \\
100.0 \%\end{array}$ & $\begin{array}{l}0.42[0.28,0.63] \\
0.43[0.38,0.50]\end{array}$ & & \\
\hline \multicolumn{7}{|c|}{$\begin{array}{l}\text { Heterogeneity: } \mathrm{Tau}^{2}=0.00 ; \mathrm{Chi}^{2}=1.35, \mathrm{df}=2( \\
\text { Test for overall effect: } \mathrm{Z}=11.43(\mathrm{P}<0.00001)\end{array}$} \\
\hline & & & & & 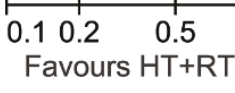 & 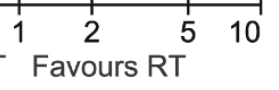 \\
\hline \multicolumn{7}{|c|}{$\begin{array}{l}\text { Figure } 7 \text { Disease Free Survival According to Treatment Duration Meta-analysis. Meta-analysis of disease-free survival, comparing hormone } \\
\text { therapy combined with radiotherapy versus radiotherapy alone in patients with non-metastatic prostate cancer, according to the time of } \\
\text { hormone treatment (up to } 6 \text { months versus } 1 \text { year or more). Abbreviations: } \mathrm{Cl}=\text { confidence interval; HT-hormone therapy; IV =Generic Inverse } \\
\text { Variance; RT-radiotherapy; SE = standard errors. }\end{array}$} \\
\hline
\end{tabular}


significant data were favourable for the use of such a protocol, there are still questions concerning the definition of high-risk patients in this study (T1 or T2 with histological grades greater than 3, or T3 and T4 with any grade). Distinct criteria among studies have limited the possibility to identify, with great accuracy, the groups expected to benefit from androgen suppression.

Moreover, there has been some discussion involving the type of radiotherapy performed, with the hypothesis that either conformational or intensity modulated treatments - by delivering higher doses of radiotherapy could reduce the necessity of androgen deprivation. This idea, however, was not proven in randomised clinical trials for high-risk patients. In low-risk prostate cancer, one prospective randomised study compared conformational versus standard external beam radiotherapy, and described a reduction of biochemical relapse from 32\% to $17 \%$, without impact on overall survival [29].

Toxicity analyses were impeded by scarce reports of adverse events in the published articles. Results from observational studies have suggested the possibility that long-term androgen suppression might be related to a higher risk of metabolic syndrome [30] and osteoporosis [31], despite the lack of such descriptions in prospective work. Taking into account the tendency of higher efficacy with a longer duration of therapy, as shown in our analysis, such knowledge should be important in future trials.

\section{Conclusions}

This meta-analysis was able to demonstrate a benefit from the combination of androgen deprivation therapy and external-beam radiotherapy for high-risk prostate cancer patients. The use of goserelin for a period longer than 1 year was associated with more beneficial survival outcomes, and should be considered standard treatment for those with higher risk of relapse. At this time, there is insufficient evidence to support other LHRH analogues or identify possible limiting long-term toxicities.

\section{Acknowledgements}

The authors wish to thank Deborah Salerno for her kind support in grammar and style.

\section{Author details \\ ${ }^{1}$ Center for Evidences in Oncology, Clinical Oncology Service, Internal Medicine Department Faculty of Medical Sciences, University of Campinas- UNICAMP, 6111, 13083-970 Campinas, SP, Brazil. ${ }^{2}$ Medical School, Federal University of Rio de Janeiro (UFRJ), Rio de Janeiro, Brazil. ${ }^{3}$ Oncology Center (Centro Oncologico), Luanda, Angola.}

\section{Authors' contributions}

ADS: conceived of the study, participated in the study design, data extraction, article selection, statistical analysis and coordination; ES: participated in the article selection, data extraction and statistical analysis; LTM: participated in the study design and manuscript preparation. AMC: participated in the study design, article selection and data extraction. All authors read and approved the final manuscript.

\section{Competing interests}

This study was sponsored and partially funded by Astra-Zeneca. The sponsor had no access or interference in the preparation of the manuscript.

Received: 23 August 2011 Accepted: 2 February 2012

Published: 2 February 2012

\section{References}

1. Jemal A, Bray F, Center MM, Ferlay J, Ward E, Forman D: Global cancer statistics. CA Cancer J Clin 2011, 61(2):69-90

2. Baade PD, Youlden DR, Krnjacki LJ: International epidemiology of prostate cancer: geographical distribution and secular trends. Mol Nutr Food Res 2009, 53(2):171-184.

3. Bray F, Lortet-Tieulent J, Ferlay J, Forman D, Auvinen A: Prostate cancer incidence and mortality trends in 37 European countries: an overview. Eur J Cancer 2010, 46(17):3040-3052.

4. D'Amico AV, Moul J, Carroll PR, Sun L, Lubeck D, Chen MH: Cancer-specific mortality after surgery or radiation for patients with clinically localized prostate cancer managed during the prostate-specific antigen era. J Clin Oncol 2003, 21(11):2163-2172.

5. Pisters LL: The challenge of locally advanced prostate cancer. Semin Oncol 1999, 26(2):202-216.

6. Hanks GE, Hanlon AL, Schultheiss TE, Freedman GM, Hunt M, Pinover WH, Movsas B: Conformal external beam treatment of prostate cancer. Urology 1997, 50(1):87-92.

7. Horwitz EM, Hanlon AL, Hanks GE: Update on the treatment of prostate cancer with external beam irradiation. Prostate 1998, 37(3):195-206.

8. Zagars GK, Johnson DE, von Eschenbach AC, Hussey DH: Adjuvant estrogen following radiation therapy for stage $C$ adenocarcinoma of the prostate: long-term results of a prospective randomized study. Int J Radiat Oncol Biol Phys 1988, 14(6):1085-1091.

9. Bolla M, Gonzalez D, Warde P, Dubois JB, Mirimanoff RO, Storme G, Bernier J, Kuten A, Sternberg C, Gil T, et al: Improved survival in patients with locally advanced prostate cancer treated with radiotherapy and goserelin. N Engl J Med 1997, 337(5):295-300.

10. Parmar MK, Torri V, Stewart L: Extracting summary statistics to perform meta-analyses of the published literature for survival endpoints. Stat Med 1998, 17(24):2815-2834.

11. Tierney JF, Stewart LA, Ghersi D, Burdett S, Sydes MR: Practical methods for incorporating summary time-to-event data into meta-analysis. Trials 2007, 8:16.

12. Sterne JA, Egger M, Smith GD: Systematic reviews in health care: Investigating and dealing with publication and other biases in metaanalysis. BMJ 2001, 323(7304):101-105.

13. DerSimonian R, Laird N: Meta-analysis in clinical trials. Control Clin Trials 1986, 7(3):177-188

14. Higgins JP, Thompson SG, Deeks JJ, Altman DG: Measuring inconsistency in meta-analyses. BMJ 2003, 327(7414):557-560.

15. Lawton CA, Winter K, Grignon D, Pilepich MV: Androgen suppression plus radiation versus radiation alone for patients with stage D1/pathologic node-positive adenocarcinoma of the prostate: updated results based on national prospective randomized trial Radiation Therapy Oncology Group 85-31. J Clin Oncol 2005, 23(4):800-807.

16. Bolla M, Van Tienhoven G, Warde P, Dubois JB, Mirimanoff RO, Storme G, Bernier J, Kuten A, Sternberg C, Billiet I, et al: External irradiation with or without long-term androgen suppression for prostate cancer with high metastatic risk: 10-year results of an EORTC randomised study. Lancet Oncol 2010, 11(11):1066-1073.

17. Granfors T, Modig H, Damber JE, Tomic R: Long-term followup of a randomized study of locally advanced prostate cancer treated with combined orchiectomy and external radiotherapy versus radiotherapy alone. J Urol 2006, 176(2):544-547.

18. Laverdiere J, Nabid A, De Bedoya LD, Ebacher A, Fortin A, Wang CS, Harel F: The efficacy and sequencing of a short course of androgen suppression on freedom from biochemical failure when administered with radiation therapy for T2-T3 prostate cancer. J Urol 2004, 171(3):1137-1140.

19. Roach M, Bae K, Speight J, Wolkov HB, Rubin P, Lee RJ, Lawton C, Valicenti R, Grignon D, Pilepich MV: Short-term neoadjuvant androgen 
deprivation therapy and external-beam radiotherapy for locally advanced prostate cancer: long-term results of RTOG 8610. J Clin Oncol 2008, 26(4):585-591.

20. D'Amico AV, Chen MH, Renshaw AA, Loffredo B, Kantoff PW: Risk of prostate cancer recurrence in men treated with radiation alone or in conjunction with combined or less than combined androgen suppression therapy. J Clin Oncol 2008, 26(18):2979-2983.

21. Jones $C U$, Hunt D, McGowan DG, Amin MB, Chetner MP, Bruner DW, Leibenhaut MH, Husain SM, Rotman M, Souhami L, et al: Radiotherapy and short-term androgen deprivation for localized prostate cancer. $N$ Engl J Med 2011, 365(2):107-118.

22. Denham JW, Steigler A, Lamb DS, Joseph D, Turner S, Matthews J, Atkinson C, North J, Christie D, Spry NA, et al: Short-term neoadjuvant androgen deprivation and radiotherapy for locally advanced prostate cancer: 10-year data from the TROG 96.01 randomised trial. Lancet Oncol 2011, 12(5):451-459.

23. See WA, Tyrrell CJ: The addition of bicalutamide $150 \mathrm{mg}$ to radiotherapy significantly improves overall survival in men with locally advanced prostate cancer. J Cancer Res Clin Oncol 2006, 132(Suppl 1):S7-16.

24. Marselos M, Tomatis L: Diethylstilboestrol: II, pharmacology, toxicology and carcinogenicity in experimental animals. Eur J Cancer 1992, 29A(1):149-155.

25. Boccafoschi C: Prostate cancer and androgen deprivation: optimal castration? Prospects and developments. Arch Ital Urol Androl 2011, 83(1):63-66.

26. Vilar Gonzalez S, Maldonado Pijuan X: Evidence-based medicine: comparative analysis of luteinizing hormone-releasing hormone analogues in combination with external beam radiation and surgery in the treatment of carcinoma of the prostate. BJU Int 2010, 107(8):1200-1208.

27. Cuppone F, Bria E, Giannarelli D, Vaccaro V, Milella M, Nistico C, Ruggeri EM, Sperduti I, Bracarda S, Pinnaro P, et al: Impact of hormonal treatment duration in combination with radiotherapy for locally advanced prostate cancer: meta-analysis of randomized trials. BMC Cancer 2010, 10:675.

28. Horwitz EM, Bae K, Hanks GE, Porter A, Grignon DJ, Brereton HD, Venkatesan V, Lawton CA, Rosenthal SA, Sandler HM, et al: Ten-year followup of radiation therapy oncology group protocol 92-02: a phase III trial of the duration of elective androgen deprivation in locally advanced prostate cancer. J Clin Oncol 2008, 26(15):2497-2504

29. Zietman AL, Bae K, Slater JD, Shipley WU, Efstathiou JA, Coen JJ, Bush DA, Lunt M, Spiegel DY, Skowronski R, et al: Randomized trial comparing conventional-dose with high-dose conformal radiation therapy in earlystage adenocarcinoma of the prostate: long-term results from proton radiation oncology group/american college of radiology 95-09. J Clin Oncol 2010, 28(7):1106-1111.

30. Braga-Basaria M, Dobs AS, Muller DC, Carducci MA, John M, Egan J, Basaria S: Metabolic syndrome in men with prostate cancer undergoing long-term androgen-deprivation therapy. J Clin Oncol 2006, 24(24):3979-3983.

31. Basaria S, Lieb J, Tang AM, DeWeese T, Carducci M, Eisenberger M, Dobs AS: Long-term effects of androgen deprivation therapy in prostate cancer patients. Clin Endocrinol (Oxf) 2002, 56(6):779-786.

Pre-publication history

The pre-publication history for this paper can be accessed here: http://www.biomedcentral.com/1471-2407/12/54/prepub

doi:10.1186/1471-2407-12-54

Cite this article as: Sasse et al: Androgenic suppression combined with radiotherapy for the treatment of prostate adenocarcinoma: a systematic review. BMC Cancer 2012 12:54.

\section{Submit your next manuscript to BioMed Central and take full advantage of:}

- Convenient online submission

- Thorough peer review

- No space constraints or color figure charges

- Immediate publication on acceptance

- Inclusion in PubMed, CAS, Scopus and Google Scholar

- Research which is freely available for redistribution

Submit your manuscript at www.biomedcentral.com/submit
Biomed Central 